\title{
INTEGRATION, COLLABORATION, RESISTANCE. THE HUNGARIAN MINORITY IN TRANSYLVANIA AND THE ROMANIAN STATE SECURITY
}

\author{
By Stefano Bottoni
}

\section{Securitate and ethnic minorities in communist Romania: an entangled history}

This paper aims to analyze the relationship between the Communist state security and the most sizeable ethnic minority in Romania, the 1,5 million Hungarian community of Transylvania. The subject of my study is not entirely new, since a number of valuable books, articles and research papers have been published so far concerning the fate of Romania's minorities under the Ceaușescu regime. ${ }^{1}$ These contributions have considerably broadened our knowledge of the discrimina-

1 The Hungarian-language bibliography on this issue is too large to be mentioned here. A good historiographical assessment in Balázs T re n c sén y i et al.: Nationalizing Minorities and Homeland Politics. The Case of the Hungarians in Romania. In: NationBuilding and Contested Identities. Romanian and Hungarian Case Studies. Budapest, Iași 2001; a balanced account in Robert R. King: Minorities under Communism. Nationalities as a Source of Tension among Balkan Communist States. Cambridge/MA 1973; i d e m: A History of the Romanian Communist Party. Stanford/CA 1980. A more revendicative stance in George Schöpflin: Witnesses to Cultural Genocide. Firsthand Reports on Rumania's Minority Policies. New York 1979; and Elemér Illy és: National Minorities in Romania: Change in Transylvania. New York 1982 (East European Monographs); for a comparation of the situation of the Hungarian minorities after 1918 see Stephen Borsody: The Hungarians: a Divided Nation. New Haven 1988 (East European Monographs); and the most recent and comprehensive synthesis: Minority Hungarian Communities in the Twentieth Century. Eds. Nándor Bár d i, Csilla Fe d in e c, László Szarka. New York 2011; among the German-language works still useful Ottmar Kola r: Rumänien und seine nationalen Minderheiten: 1918 bis heute. Wien 1997; among the post-1989 Romanian contributions, one worth mentioning the two-volume series by Andrea And ree scu, Lucian N a s t a să, Andrea V a r g a: Minorități etnoculturale. Maghiarii din România [Ethnic minorities. Hungarians of Romania] 1945-1955. Centrul de Resurse pentru Diversitatea Etnoculturală. Cluj-Napoca 2002; Minorități etnoculturale. Maghiarii din România [Ethnic minorities. Hungarians of Romania] 1955-1968. Centrul de Resurse pentru Diversitatea Etnoculturală. Cluj-Napoca 2003. 
tive policies carried out towards ethnic minorities by the Romanian communist system, touching upon relevant topics such as postwar deportation and resettlement, social deprivation following the nationalization campaign, linguistic rights, religious freedom, and migration to the West. As Walker Connor and Martin Mevius have pointed out in their large-scale comparative analysis of Communist nationalities policies during the Cold War, a basic contradiction affected the interplay between ideology (the Marxist-Leninist theoretical premise) and practice that is the compromise between internationalist utopia and realpolitik. In the postwar context, this meant a widely shared agreement between the various political parties on the necessity to "nationalize" the multiethnic territories of Central Europe by removing undesirable minorities. ${ }^{2}$ My research aims to put the majority-minority relation in a State security perspective, helping to understand the historical importance for the internal evolution of the Romanian communist regime and its relation system with the Hungarian community of two major crises generated by external events, such as the 1956 Hungarian revolution and the 1968 Prague Spring.

To understand the Securitate's policy towards the largest minority in Romania, it is very important to place the events into a new interpretative context. Earlier works on Romania's minority policy under Gheorghiu-Dej and Ceaușescu focused almost exclusively on human rights' violations committed by the Communist regime, and downplayed the active role of the minority communities. New scholarship recently published in Romania and Germany ${ }^{3}$ demonstrates, however,

\footnotetext{
${ }^{2}$ Walker Connor: The National Question in Marxist-Leninist Theory and Strategy, Princeton (NJ) 1984; a good up-to-date introduction to the comparative study of national policies in the Soviet Bloc in Martin Mevius: Reappraising Communism and Nationalism. In: Nationalities Papers. Vol. 37, no. 4, July 2009, pp. 378-400; on the Hungarian Communist Party's approach to nationalism and the Hungarian minorities, Martin Me vi u s: Agents of Moscow. The Hungarian Communist Party and the Origins of Socialist Patriotism, 1941-1953. Oxford 2005.

${ }^{3}$ Stejărel Olaru, Georg He r b stritt:Stasi și Securitatea [GDR-and SSR-Intelligence Service]. București 2005; Anca Ci u ci u : Acțiunea "credinciosul": șef rabinul Moses Rosen și comunitatea evreiască în arhivele CNSAS [Operation "Believer". Chief rabbi M.R. and the Jewish community at the archives of CNSAS]. București 2008; Acțiunea "Recuperarea". Securitatea și emigrarea germanilor din România [Operation "Recuparation". Securitate and the emigration of germans from Romania] (1962-1989). Eds. Florica D o b r e et al. București 2011; the most relevant works concerning the state security actions against the Hungarian community are Márton László: Magyarhermány kronológiája [The chronology of Magyarhermány / ro. Herculian] (1944-1964). Miercurea Ciuc 2008; János Molnár: Szigorúan ellenőrzött evangélium [Strictly controlled Gospel]. Nagyvárad 2009; Csaba Zoltán Novák: Aranykorszak? A Ceaușescu-rendszer magyarságpolitikája [Golden Age? The Hungarian-policy of the Ceaușescu regime] 1965-1974. Csíkszereda
} 
how fascinating and intricate the nationality issue was in communist Romania. Making use of previously inaccessible sources from the former secret police archives, these authors explore the activity of the security forces among and against ethnic minorities, but also the numerous cases of individual collaboration among the non-Romanian elites. This new scholarship challenges the widely shared view that central and local Romanian authorities are the only responsible for the mistreatment of minorities, discharging former collaborators as victims of an infernal mechanism. Professional historians dealing with ethnic relations in communist Romania still deal with the pernicious effect of self-victimizing, traumatic collective memory elaborated by minority groups during the 1980s, which easily becomes a defensive strategy against new, unpleasant findings about the complex relational network between the Romanian state security and the minority groups.

My paper aims at contributing to a methodological renewal of historical research on interethnic relations in Transylvania by analyzing not only the concrete policies carried out by the Romanian authorities, but also the behind-the-scene organizational and ideological changes affecting Securitate. The fundamental shift of the Romanian secret police from strict internationalism and class repression to open support for soft ethnic cleansing can be considered as one of the most interesting features of the most general changes the Romanian communist regime underwent from the late 1950s onwards.

\section{The age of State-sponsored integration}

The dilemma the Romanian communist party had to face after 1944 was common to left-wing parties of all newly established Soviet-sponsored "popular democracies". On the one hand, their leaders and especially the rank-and-file members were not insensible to nationalist arguments. On the other hand, communist parties in the territories liberated/occupied by the Red Army had a multiethnic composition, and rejected "bourgeois" nationalism. External factors, such as the Soviet military occupation and Hungary's position as a potential ally of Romania, also contributed to make the Romanian case an exception among the postwar Eastern European nations. Stalin firmly opposed ethnic revenge on the defeated Hungarian minority in Transylvania and ordered his representatives to support ethnic pacification of the province. Unlike in Czechoslovakia, where the Hungarians suffered for several years legal discrimination and forced resettlement, and similarly to Bulgaria,

2010. - William Totok: Minderheiten und Securitate. In: Halbjahresschrift für südosteuropäische Geschichte, Literatur und Politik 23 (2011), H. 1-2 (Herbst), pp. 77-110. 
where the communist party offered cultural rights to the previously persecuted Muslim and Turk communities, Romania's first left-wing government led by Petru Groza proclaimed the political and social integration of ethnic minorities regardless of their war record. Plans of population exchanges with Hungary involving hundred thousand ethnic Hungarians from Transylvania had been issued in 1945-46 by the Office for Peace preparation of the Ministry of External Affairs, but were never implemented due to Soviet opposition. Interethnic violence in postwar Transylvania did occur against the Hungarian and the Ukrainian minority, but retribution did not become the pattern of Romanian minority policy. The only relevant exception to this integrative stance was the harsh punishment inflicted to the German minority, who was proclaimed collectively guilty of collaboration with Nazi Germany. In January 1945, a deportation campaign affected some 70,000 ethnic German civilians - ca. 15\% of Transylvania's German population according to 1941 data - who suffered deportation from Satu Mare, Maramureș and Sălaj, Banat and Transylvanian counties to Soviet work colonies ("reconstruction work" as an instrument of reparation and retribution for war damages), along with ethnic Germans from other East-European countries. The relevant operative plans for this were issued by the Soviet security forces according to Stalin's directions. ${ }^{4}$ Consistent proofs have also emerged showing the involvement of Romanian authorities in an act of cleansing resulting in more than 3,000 victims. ${ }^{5}$ Nevertheless, the 1945 deportation of Swabians was not followed by general plans of expulsion of the whole ethnic German population. Although Transylvanian Saxons and Swabians were excluded from the 1945 land reform, and were condemned to judicial discrimination as second-class citizens until 1949, they were not exposed to physical annihilation. ${ }^{6}$

Between 1945 and 1956, the integration of minority groups was generally encouraged by the Romanian state. Gaining the political support of non-Romanians in which remained, after all, a multinational entity, became one of the main goals of the left-wing government led by Petru Groza and supported by the Soviet Union. A number of internal and

4 The historical framework of post-1939 special operations carried out by Soviet security forces in Pavel Polian: Against Their Will. The History and Geography of Forced Migration in the USSR. Budapest 2004.

5 Vladimir Tismăneanu, Dorin Dobrincu, Cristian Vasile: Raport Final. Comisia Prezidențială pentru Analiza Dictaturii Comuniste din România [Final report. An analysis of communist dictatorship in Romania by the presidents' commission]. București 2007, pp. 358-359.

${ }^{6}$ See the well-balanced account by Hannelore Baier in: Tis măneanu et al., op. cit., pp. 355-357. 
external factors made the Romanian-Hungarian compromise possible. Moscow wanted to achieve ethnic peace and cooperation in Romania, and Stalin looked at Transylvania as part of a broader scenario which included Bessarabia and Northern Bukovina. As a compensation for the definitive loss of the two regions vindicated by the USSR, Romania was granted the whole Transylvania under the condition that a "truly democratic", pro-Soviet government was set up in Bucharest. On the Hungarian side, the loss of Northern Transylvania after World War II was painful, but not shocking: well before the Paris peace treaty of February 1947 put an end to the diplomatic conflict, Hungary had faced harsh Soviet refusal to any plans of territorial adjustments, and its war record of "last" Nazi ally put Hungary in weak position faced to Romania. After some failed attempts to regain its role of external homeland and diplomatic helper of its diaspora, Budapest had to accomodate to the basic principle of bilateral relations in the Soviet sphere: minority issue is par excellence an internal affair and shall never be discussed in public. On the ground, the majority-minority relationship also went through major changes. After 1945, the 1, 5 million Transylvanian Hungarians, whose social, cultural and even demographic influence remained considerate in spite of the massive emigration of its middle class, accepted the compromise the Romanian state offered for their political loyalty: political integration without any pressure for cultural assimilation. The Romanian governments carried out with the Hungarians a policy resembling the Leninist korenizatsia of the early 1920s. For almost a decade, left-wing (since 1948 Stalinist) Hungarian cultural life was generously supported, and a full-scale educational network was allowed to exist throughout Transylvania. This positive approach contrasted with the discriminative policies of the interwar period, and stimulated popular participation from the Hungarian side, as well. The best expression of left-wing activism was the Hungarian Popular Union (HPU - 1944-1953), a minority organization which came to number half a million members (one ethnic Hungarian adult out of two) and gaining almost $10 \%$ of national ballots and 30 parliamentary seats at the November 1946 partially free elections. According to scholars Nagy Mihály, Ágoston Olti and Tamás Lönhárt, HPU and its political leaders played a double and contradictory role in the transition years to the one-party system: they acted as a spokesman and defender of the Hungarian interests, claiming for more integration and financial support to minority culture, but they represented also a Trojan horse for the penetration of Communist social radicalism into the Hungarian community, especially among workers and poorer peasants. Most prominent members and rank-and-file activists of the HPU were also 
members of the Communist party, and originally combined the ethnic discourse and the ideological allegiance to internationalism. ${ }^{7}$

From 1948 the Communist party acted as the main integrative network for the Hungarian minority. This strategy went far beyond the ruthless application of "salami tactics" against the opposition forces and their own allies within the short-lived popular fronts. In a difficult context, such as multi-ethnic Transylvania where the Hungarian presence seemed to represent a direct threat to state security, a complex mechanism of ethnic balance and power-sharing, consciously built up by the PCR with Soviet assistance from early 1945, helped the party to strengthen its political legitimacy among different national and social groups. Unlike the historical Romanian parties and the Hungarian nationalists, the PCR and the Petru Groza-led pro-communist government behaved as a multi-ethnic entity pursuing integrative policies. Starting from 1948, the new Communist state needed a huge number of politically reliable cadres of "healthy" social background. Archival data show that preferential access to the state and party apparatus was granted to ethnic minorities in the 1948-52 period. Due to their number, the Hungarians were the main beneficiaries of this policy of ethnic promotion. This helps to explain why in Hungarian-inhabited areas of Transylvania the popular support for the RCP and the communist regime was in the early 1950s considerably higher than in other Romanian provinces. Between 1949-53, the mostly Hungarian inhabited areas of the Szeklerland in Eastern Transylvania were among the very few areas of the Romanian countryside not to be affected by peasant revolts and partisan activity against the collectivization campaign. Tolerance of the Communist regime, if not proper support, was greatly helped by the "affirmative action". Ruthless class warfare against "kulaks", the "clerical reactions" and the "remains of the bourgeoisie" there did not gain any ethnic connotation (the Romanian state fighting against the Hungarian peasantry), because the State officers, tax collectors, managers, policemen or local party secretaries, were ethnic Hungarian and were perceived to be closer to the local population, although recent scholarship (Gagyi, Oláh, Novák) tend to demonstrate that they proved to be reliable apparatchiks rather than carriers of ethnic concerns.

7 Érdekképviselet vagy pártpolitika? Iratok a Magyar Népi Szövetség történetéhez [Representation of interests or party politics? Documents concerning the history of the Hungarian Popular Union] 1944-1953. Eds. Mihály Zoltán Na gy, Ágoston Olti . Csíkszereda 2009; Tamás L ö n h á r t: Uniunea Populară Maghiară în perioada instaurării regimului comunist în România [ Hungarian Popular Union during the implementation of communist rule in Romania] (1944-1948). Cluj-Napoca 2008. 
One of the most interesting features of the political integration of the Hungarian minority concerned the massive recruitment of ethnic Hungarian officers and sub-officers into the Securitate. Until 1948, figures on the social, ethnic and political composition of state security bodies - the "civil" internal intelligence (Siguranţă), the criminal investigative department handled by the PCR (Corpul Detectivilor), and the highly effective military counterintelligence (Serviciul Special de Informatii - SSI) - show a high degree of continuity with the pre-war public administration. It was reported that, after 6 March 1945, about $40 \%$ of the 6,300 state security officers were assigned to the reserve, but only 195 were fired. In June 1946 the communist minister of Interior, Teohari Georgescu, reported that despite the party's effort to set up a more "reliable" and committed security force made up of former communist activists, over $40 \%$ of the 8,500 information officers had been appointed before $1944 .{ }^{8}$ Old-style police and SSI officers, who had been trained during the interwar period, shared a double-faced attitude towards minorities. While implementing the policy of selective integration of democratic non-Romanians into the new state offered by the Groza government, they maintained the traditional concern that minorities might represent a security threat. In the years of transition, the SSI and the local police corps actively monitored and persecuted any form of Hungarian revisionism (even under the lighter form of calls for territorial or cultural autonomy), and also kept under strict surveillance the strong (and still legal) Zionist movement. ${ }^{9}$

These repressive bodies underwent a radical change only after the abolition of monarchy on 30 December 1947 and the subsequent formalization of exclusive communist rule. In August 1948 Departamentul Securităţii Statului (Securitate), a Soviet modelled political police, replaced the Siguranța and started harsh political repression with the

8 Dennis Deletant: România sub regimul comunist [Romania under communist rule]. București 2006, p. 67.

${ }^{9}$ See the report issued by Corpul Detectivilor from 15 June 1945 on the infiltration of "fascist elements" into the Hungarian Popular Union, the pro-communist mass organization of the Transylvanian Hungarians. Arhivele Naționale ale României, fond Comitetul Central al PCR, secția organizatorică, dosar 31/1945. Investigations against the Hungarian minority's activity are also reported in Andreescu et al.: Maghiarii din România, op. cit.; the Groza government ambiguous approach towards the Jewish minority is treated in ei d .: Evreii din România 1945-1965 [Jews of Romania 1945-1965]. Cluj-Napoca, Centru de resurse pentru diversitate etnoculturală 2003; see also Liviu Rot m a n: Evreii din România în perioada comunistă [Jews of Romania in the communist period] 1945-1965. Iași 2004. On the so-called "Jewish problem" in the years of transition of power, also see the large documentation of the Securitate archives (Arhiva Națională pentru Studierea Arhivelor Securității / ACNSAS, fond Documentar, dosar pp. 151-164). 
military support of nearly 70,000 security troops (Trupele Securitătii). In January 1949 another military body, the Militia, inherited the tasks of the Jandarmeria, and guaranteed the police forces' capillary presence in every single community in the country. Some Romanian scholars and former Securitate officers (Cosma, Evgeni Tanase) have argued that until 1952, when most Jews and a large number of Hungarians were purged from the state security, Securitate and the higher party organs such as the Central Committee and its sections were perceived by the Romanian majority as "alien" bodies, where ethnic Hungarians, Jews, and Ukrainians were over-represented and ruled, sometimes manifesting open hostility against the ethnic majority. ${ }^{10}$ Compared to other communist countries, the Romanian openness to minorities in such a sensitive issue may sound inexplicable. In fact, the few thousand Securitate officers working in the central apparatus were overwhelmingly of Romanian ethnic background (around 80\% in 1949, nearly $85 \%$ ten years later $\left.{ }^{11}\right)$. Beside the long-standing minister of Defence, Leontin Sălăjan (called Levente Szilágyi), some ethnic Hungarians who had belonged to the pre-war illegal RCP acceded the highest ranks of the early Securitate. Among the others, one should mention the two vice-ministers appointed in 1952 by Alexandru Drăghici: Ion Vințe (János Vincze), who was also responsible for Securitate troops, antipartisan war) with the military rank of General Mayor, ${ }^{12}$ and Alexandru Mureșanu, whose real name was László Ady. ${ }^{13}$ Between 1951 and 1953 Mureșanu/Ady was among the members of the special ministerial commission responsible for sentencing over 15 thousand citizens to forced displacement. Another ethnic Hungarian officer appointed in a key position was the Cluj-born Ferenc Butyka, who joined the Securitate after a short apprenticeship at the Cadre section of the regional Party committee and thanks to his loyalty became the head of the criminal investigation central office between 1952

10 This provoked in the late 1940s several conflicts between "Romanian" institutions and the ethnic minorities, and also serious misunderstandings within the state security apparatus itself. See the documentation preserved by the Mureș county branch of the Romanian National Archives (Arhivele Naționale din România, Direcția Regională Ergänzung a Ministerului de Afaceri Interne Mureș - Regiunea Autonomă Maghiară 1923-1967, OK ??? fond 594).

11 And reescu et al.: Maghiarii din România, op. cit., p. 26.

12 Securitatea. Structuri - cadre. Obiective și metode [Securitate. Structures-cadres. Objectives and methods]. Eds. Florica Dobre, Elis Neagoe-Pleșa, Liviu Pleșa. Vol. 1 (1948-1967). București 2006, p. 62.

13 Ibidem, p. 70. 
and 1963, where he gained a sinister fame due to his uncontrolled brutality. ${ }^{14}$

At the peak of mass repression, between 1949 and 1953, Securitate strictly followed the party's line. What Marius Oprea has called "state terrorism" against its own citizens targeted not only specific, albeit sometimes fictive "crimes" (ideological diversion, political resistance, personal misconduct), but also specific social groups. Repression was given political, professional and geographic aims, obsessively motivated by security concerns. The two great repressive waves of 1949-53 and 1958-61 primarily targeted the rural population, members of all faiths, former capitalists, and aristocrats. Thousands of people were physically removed from their property after 1949. It also hit people living in the multi-ethnic Banat region along the border with Yugoslavia, more than 45,000 of whom were forcibly relocated for security reasons to the Bărăgan Plain in June 1951. Nevertheless, political and social repression did not target any ethnic group in particular with the early exception of the Germans. Hungarians were not persecuted as Hungarians but as "former exploiters", nationalists or "kulaks". Until 1956, Hungarian nationalism and irredentism did not constitute a priority for Romanian state security. In Cluj region, for instance, the subunit responsible for internal political enemies (Serviciul III. Informații interne) was divided into six offices, and only the second one was assigned with the task to deal with "bourgeois parties, Trotskyites, Hungarian and German nationalists", ${ }^{15}$ while great efforts were made to weaken the still active clandestine Iron Guard and to fight armed resistance in the mountains. The most notable exception to this was the arrest and condemnation of the Roman Catholic bishop of Alba Iulia, Áron Márton, who was sentenced to life long forced labour in 1951 along with fellow believers and members of the Hungarian aristocracy. Among the accusations, one finds the alleged plot machinated in 1946 under the leadership of Márton, aimed at separating Transylvania from Romania. ${ }^{16}$

The first turning point in the state security's approach towards minority policy came in 1952, when Romania, on Soviet insistence, created a Hungarian Autonomous Region in the Szeklerland. The autonomous region reflected the Soviet Leninist principles of territorial federalism;

14 See Marius O p rea: Bastionul cruzimii. O istorie a Securității [Bastion of cruelty. A history of Securitate] (1948-1964). Iași 2008, pp. 228-229.

15 Liviu Pleșa: Direcția Regională de Securitate Cluj (1948-1968). Organizarea, personalul și direcțiile de acțiune [Regional head office of the Securitate at Cluj (19481968). Organization, staff and work instructions]. Anuarul Institutului de Investigare a Crimelor Comunismului și Memoria Exilului Românesc (IICCMER), 2011, p. 119.

16 Áron Márton's trial is documented in ACNSAS, fond Penal, dosar 254. 
according to the Soviet constitution, national minorities were granted areas in which they could enjoy linguistic and cultural rights. The idea was mooted on 7 September 1951, by two Soviet advisers seconded to Romania. After long discussions, the region's creation was proclaimed by the new Constitution issued on 21 September 1952. According to the 1956 census, its 13,500 square km contained 731,387 inhabitants, of whom 565,510 (77.3\%) declared themselves to be of Hungarian ethnicity. In the regional capital Târgu Mureș (Marosvásárhely), a similar proportion of Hungarians (74\%) could be found. Hungarians also provided some $80 \%$ of the party leadership and public officials, including the Communist Party first secretary (Lajos Csupor), the president of the People's Council/Consiliul Popular (Pál Bugyi) and the regional head of the Securitate (colonel Mihály Kovács, who held this position until the administrative reshaping of 1961). These men, though, owed their first loyalty to the Romanian party state and did not pursue politics on a national basis. Colonel Kovács, for instance, had been implicated with other fellow officers in the execution of three peasants on 17 August 1950, when he was leading the district office of Turda, near the city of Cluj. "Autonomy" in this case did not mean self-determination: the Hungarian Autonomous Region was under the same tight control as the other Romanian provinces, and had to implement decisions taken by central authorities. But, at the same time, outside the Hungarian Autonomous Region Hungarians in positions of authority began to be systematically removed; while inside it Hungarian could be used freely at all levels of administration, and several cultural institutions were created. ${ }^{17}$

In extreme times, such as during the far-reaching purges of 1952-53, following Ana Pauker's fall, a formal autonomy could even offer some protection from external dangers. The mass terror of "full blown" Romanian Stalinism spared the Szeklerland and the Hungarian "titular" community, because the political leadership gave instructions to the security forces not to strike unnecessarily against ethnic Hungarians in the newly established region. Outside of it, on the contrary, ethnic Hungarians suffered severe consequences, as for instance in the city of Cluj, where several hundred people were arrested under the accusation of "right-wing" deviationism. The ethnic composition of the regional branches of the Securitate in Transylvania was extremely mixed until the late 1950s. State security officers of Hungarian background (or Jewish-Hungarian descent, who were mostly identified as Hungarians)

17 A full account of the Hungarian Autonomous Region: Stefano B ot to ni: Sztálin a székelyeknél. A Magyar Autonóm Tartomány története [Stalin in the Szeklerland. The history of the Hungarian Autonomous Region] 1952-1960. Csíkszereda 2008. 
made up over $70 \%$ officers in the Hungarian Autonomous Region, as the following chart shows:

Table 1. State security and the Army's ethnic composition in the Hungarian Autonomous Region, $1956 .^{18}$

\begin{tabular}{|l|c|c|c|c|c|c|}
\hline $\begin{array}{l}\text { Ethnic } \\
\text { background }\end{array}$ & $\begin{array}{c}\text { Securitate } \\
\text { operative } \\
\text { staff }\end{array}$ & $\begin{array}{c}\text { Police } \\
\text { (Militia) } \\
\text { total staff }\end{array}$ & $\begin{array}{c}\text { Militia's } \\
\text { operative } \\
\text { staff }\end{array}$ & $\begin{array}{c}\text { Militia } \\
\text { admini- } \\
\text { strative } \\
\text { staff } \\
\%\end{array}$ & $\begin{array}{c}\text { Army's } \\
\text { regional } \\
\text { command- } \\
\text { total staff } \\
\%\end{array}$ & $\begin{array}{c}\text { Regional } \\
\text { Army's } \\
\text { command- } \\
\text { officers } \\
\%\end{array}$ \\
\hline Hungarian & 71 & 60 & 62 & 48,4 & 26 & 3 \\
\hline Romanian & 20 & 38 & 34,6 & 51 & 74 & 97 \\
\hline $\begin{array}{l}\text { Other } \\
\text { (German, } \\
\text { Jew, Roma) }\end{array}$ & 9 & 2 & 3,4 & 0,6 & $/$ & $/$ \\
\hline
\end{tabular}

Even more significantly, Hungarian-speaking Securitate officers were a majority in mostly Hungarian-inhabited cities like Oradea and Satu Mare, while in mixed localities such as Timișoara, Brașov and Arad their percentage started to decline quite early. As for the "civil" police, called Miliția, and the local Army commands, these always showed a preference for ethnic Romanian cadres. Nevertheless, the new system was effective in the stimulation of "civic" loyalty towards populardemocratic Romania. Hungarian-born officers tended to speak the state's official language while on duty and in their private lives, and even when speaking their mother tongue they could not forget the (Romanian) context in which they were operating. Cluj, the intellectual crossroad of Transylvania whose population was still predominantly Hungarian in the 1950s, has been recently the object of the first systematic sociological analysis of a regional security branch by Romanian historian Liviu Pleșa. ${ }^{19}$ According to his findings, Cluj and its surroundings represented one of the most sensitive regional branches due to the symbolic importance of the city: Securitate had only 141 staff in 1948, but their number rapidly increased to over 600 employees in 1956. As Pleșa points out, the first generation of chief-officers shared an illegal communist background and battleground experience during the Spanish civil war and/or the Second World War, with an overwhelming presence of Hungarian-Jewish born officers. ${ }^{20}$ It is worth mentioning two of them. The first is Mihai Patriciu (his real name was Grünsperger), the chief of regional security in 1945-51. He was

\footnotetext{
18 B ott oni: Sztálin a székelyeknél, op. cit., p. 159.

19 Pleșa: Direcția Regională, op. cit., pp. 115-145.

20 For a complete list see Pleșa: op. cit., p. 129.
} 
active in Spain and in the French resistance movement, coming back to Romania in late 1944. Due to his close relations to former Minister of Interior Teohari Georgescu, he fell in disgrace in 1952 along with his protector. Even more fascinating appears the case of Wilhelm Einhorn, born in Cojocna on 2 March 1911, who joined the illegal Communist movement, left for Spain in 1937 and was then imprisoned in France along with his later superior, Mihai Patriciu. Then he succeeded to escape to the Soviet Union, and later followed the Soviet troops' march into Central Europe, being recruited as a Romanian specialist by the NKVD. He returned to Cluj in January 1945, where he was involved in the organization of the new Popular Police, and in April, the same year, was appointed regional chief of Siguranța. Between 1948 and 1960 he held key positions in the central apparatus of Securitate, and in early 1957 was even sent to Hungary under diplomatic cover to help reorganize the Hungarian secret police and unmask political opponents of the freshly established Kádár regime. ${ }^{21}$ In many respects, Pleșa's work follows earlier researches, such as Marius Oprea's monumental inquiry into the Romanian communist repressive body, or Florian Banu's analysis of the 1950s cadre policy within this institution, who underline the poor professional background of Securitate officers. ${ }^{22}$ At the same time, Pleșa made some interesting points regarding the ethnic composition of the Securitate staff of Cluj region and the importance of the Hungarian nationalism as a state security issue. According to his research, at a regional level the Hungarian-born officers made up almost one third of the 617 operative staff in 1956; ${ }^{23}$ their numbers sharply declined starting from the first half of the 1960s, when the regional branch of Cluj was put under the direction of a young, ambitious and well-connected officer named Nicolae Pleșiță. As he claims in his memoirs, at his arrival to Cluj in 1962 Pleșiță was shocked to find so many first-generation Hungarian officers in the state security, and immediately started to "romanize" the secret police by removing Hungarians and promoting young Romanian-born cadres, who

${ }^{21}$ More information of Einhorn in the documentary collection: Az 1956-os forradalom és a romániai magyarság 1956-1959 [The revolution of 1956 and the Hungarian minority in Romania 1956-1959]. Eds. Stefano B ot to ni et al. Csíkszereda 2006, p. 37 and pp. 252-255 (document no. 73).

22 Marius O prea: Banalitatea răului. O istorie a Securității în documente [Banality of evil. A history of Securitate according to its documents]. Iași 2002. See also Florian B anu: Rețeaua informativă a Securității în anii '50: constituire, structură, eficiență [Network of information of Securitate in the fifties: formation, structure, efficiency]. Caiete CNSAS 2 (2008), pp. 7-38.

23 Pleșa: Direcția Regională, op. cit., p. 130. 
had been educated in a national-communist spirit and perceived the Hungarians as a collective threat. ${ }^{24}$

\section{Turning points: 1956 and 1968 in a State security perspective}

The 1956 Hungarian revolution had an outstanding impact on the internal dynamics of the communist system of neighbouring Romania. The unforeseen and dramatic collapse of all main Hungarian power agencies alarmed the Bucharest party leadership. The first party secretary Gheorghe Gheorghiu-Dej put the army, the intelligence and the diplomatic corps on highest alert. In fact, no mass actions or armed disturbances took place in Romania during the Hungarian revolt, not even in the most densely Hungarian-inhabited regions (a student rally held on October 30-31 in Timișoara was an exception, not the rule). The reception of the 1956 Hungarian Revolution by Hungarians in neighboring countries was ambivalent. It was hoped that the Revolution's democratic and national demands could be met, but it was feared that reprisals for failure might spread to all Hungarians who had shown sympathy. Still, there were some small initiatives, although the rebels in Budapest had not voiced any demands for the minority Hungarians. The Roman Catholic priest Aladár Szoboszlai, based in Arad, set about organizing a national conspiracy to overthrow the communists and achieve a Romanian-Hungarian confederation. This was soon broken up by the Romanian secret police, the Securitate, who arrested the conspirators. When they came to trial in 1958, ten main conspirators were executed and 47 others received sentences ranging from several years' imprisonment to lifelong hard labor. ${ }^{25}$ Still, the Szoboszlai trial remains almost unknown despite being the largest politically motivated indictment ever carried out in post-1945 Romania. There were protests around Oradea and in the Szeklerland, organized by the Transylvanian Hungarian youth associations, which consisted mainly of secondary school pupils. Intervention by the Romanian Communist

${ }^{24}$ Ochii și urechile poporului. Convorbiri cu generalul Nicolae Pleșiță [Eyes and Ears of the People. Talks with general N.P.]. Eds. Anca Voican, Marian Oprea. București 2001.

25 Proceedings of the trial have been collected and translated into Hungarian by Zoltán Tó falvi: 1956 erdélyi mártírjai I. A Szoboszlai-csoport [The Transylvanian Martyrs of 1956. The group Szoboszlai]. Marosvásárhely 2007. On Szoboszlai's plot attempt see also Stefano B o t t o n i : A hontalan forradalmár - Reflexiók Szoboszlay Aladár ügyére [The homeless revolutionary - Reflections to the case of Aladár Szoboszlay]. In: Magyar Kisebbség 3 (2004), pp. 143-160, and i d e m: 1956 Romániában: Szoboszlay Aladár forradalma [The year 1956 in Romania: The revolution of Aladár Szoboszlay]. In: Limes 4 (2006), H. 4, pp. 37-50. 
Party and the Securitate led to severe reprisals, from November 1956 to the early 1960s, for all who had shown sympathy for the Hungarian cause. Also arrested and condemned were young people, some minors, who tried to cross the border into Hungary to join the struggle. One female student from Cluj received a ten-year prison sentence for sending a letter to a friend into which she had copied the poem "A Word about Tyranny" by the Hungarian writer Gyula Illyés. Initially the reprisals were against the whole society, but from 1957 onwards, repression affected an increasing number of professionals and intellectuals accused of cosmopolitism, and also teachers, traders, civil servants and even party and police officers. Furthermore, there could be noticed a growing shift from indiscriminate purges to more selective and ethnically founded punishment, targeting non-Romanian minorities, especially Jews, Transylvanian Hungarians - above all their intelligentsia - and (to a lesser extent) Germans, Jews and Russians/Ukrainians. Recent research indicates the number of people directly affected by the purges carried out between 1956 and 1961 to almost 30,000, of who well over one tenth were ethnic Hungarians. ${ }^{26}$ But Romania's increasingly nationalist course cannot be simply explained by, as some scholars did, the "lessons learnt" by the Romanian communist leadership in $1956 .{ }^{27}$ Well before Nicolae Ceaușescu's seizure of power in 1965, the official party line asserted the struggle for economic independence, the withdrawal of the Soviet occupation army and an increasing effort to "nationalize" the country by limiting the cultural rights of its most sizeable ethnic minority, the Hungarian one. The main feature of the Romanian reception of the 1956 Hungarian revolution was the launch of a severe repression despite no revolutionary events or other serious threat to state security had occurred. The "ethnic" interpretation given by the Bucharest communist leadership to the failed revolution

26 Stefano B ott on i: Transilvania roșie. Comunismul român și problema națională [The red Transylvania. Romanian communism and the ethnic problem] 1944-1965. Cluj-Napoca 2010, p. 250.

27 On the official interpretation of the 1956 Hungarian events by the Romanian communist authorities see Johanna Granville: Dej-a-Vu: Early Roots of Romania's Independence. In: East European Quarterly 4 (2008), pp. 365-404; Temporary Triumph in Timișoara: Unrest among Romanian Students in 1956. In: History. The Journal of the Historical Association, 309 (January 2008), pp. 69-93; Forewarned is Forearmed: How the Hungarian Crisis of 1956 Helped the Romanian Leadership. In: Europe-Asia Studies 4 (2010), pp. 615-645; Hungary. 101: Seven Ways to Avoid a Revolution and Soviet Invasion of Romania. In: Cold War History 1 (2010), pp. 81-106; see also Dragoș Pe tr e s cu: Fifty-Six as an identity shaping experience: The case of the Romanian communists. In: The 1956 revolution and the Soviet Bloc countries: Reaction and Repercussions. Eds. János Rainer, Katalin Som lai. Budapest 2007, pp. 48-68. 
in Hungary provided also the ground for a more general ideological reassessment of the Romanian communist regime. The most evident signs of that were a radical change of approach in minority issues, the struggle for self-distancing from Moscow and finally the transformation of nationalistic policy into a coherent national-communist doctrine under Nicolae Ceaușescu's leadership.

The 1956 Revolution brought about a change mainly in minority policy in Romania, where the minority elite had made a more active contribution to local and national administration compared to the other neighbouring countries. The moral of 1956 for the Romanian regime was that ethnic Hungarians still saw Hungary as their mother country, despite all the concessions and ostensible privileges given to them, and showed no desire to integrate into the Romanian state. So they had to be classed as an unreliable element even if they posed no direct threat to the country's territorial integrity. In 1959, the Hungarian Bolyai University in Cluj was merged into the Romanian-taught Babeș University. In 1960, elementary and secondary schools teaching in Hungarian began to be merged with Romanian schools. In the end, on 24 December 1960, the Parliament passed a constitutional amendment altering the region's boundaries. To be known henceforth as the Maros-Hungarian Autonomous Region (RMAM), its territory and ethnic composition were substantially altered. Two Szekler districts were transferred to the Braşov region, and the districts of Sărmaș, Târnăveni and Ludus, with a Hungarian proportion of around 20 percent, were annexed to the Maros-Hungarian Autonomous Region, making it a larger region with about 800,000 inhabitants, of whom $61 \%$ were Hungarian and $35 \%$ Romanian. ${ }^{28}$ A politically driven change of elite during 1961 replaced most of the Hungarian and Jewish functionaries with Romanian cadres. ${ }^{29}$ Although the Romanian authorities were forced by Soviet pressure into agreeing in 1952 to set up the Hungarian Autonomous Region, they made good use of it in subsequent years to justify pursuing homogenization in other parts of Transylvania, mainly in the cities, and refusing to recognize the minority's specific cultural and social heritage and needs. Classes taught in Romanian were added to Hungarian educational institutions at lower and higher levels. Mergers of schools in multi-ethnic communities resulted in parallel sections and classes, while Romanian-taught courses were introduced into hitherto Hungarian-taught schools. The direct outcome was a fall in enrolment in Hungarian-taught secondary education. The nationalist

28 B ott oni: Sztálin a székelyeknél, op. cit., p. 418.

29 B ott oni: Sztálin a székelyeknél. op. cit., pp. 422-424. 
turn of Romanian communism was also reflected in new terminology referring to non-Romanian ethnic groups. In 1959, the term "national minority" and the previously frequent references to the "multinational" character of the Romanian state were ousted by a new definition, "the Romanian people and the cohabiting national groups". According to party ideologists, "national minority" implied forming a separate cultural nation. The hitherto large number of Hungarians working in the party and state apparatus found themselves squeezed out, along with the Jewish-born officials who were Hungarian in culture. From 1957 onwards, the secret police used blackmail and other methods to start a mass recruitment campaign among ethnic Hungarians as informers on other members of the Hungarian community. ${ }^{30}$ This applied particularly in the arts, the universities and newspaper offices, but it extended to factories and state institutions as well. Romania's minority policy in the 1960s was guided by the so called nation-building stage in the transformation into a communist society. The progressive shift from a class-dictatorship toward an ethnicized totalitarian regime was the product of the Gheorghiu-Dej era and, as such, it was nothing but the natural outcome of a long-standing ideological fouling of communism and more traditional state-building ideologies. ${ }^{31}$

A good mirror of how the political changes penetrated the mentality of state security is a comparative analysis of speeches held by the minister of Interior, Alexandru Drăghici, during the operative meetings held throughout the 1950s. In a speech held on 11 February 1953 in front of the chiefs of the regional branches of the Securitate, Drăghici - whose wife was incidentally an ethnic Hungarian - blamed the poorly coordinated actions taken against "hostile elements" and "fugitives", but made no reference to Hungarian "nationalist" threat. ${ }^{32}$ Thus, individual crimes and "faults" committed by ethnic Hungarians were explained in strictly ideological terms (criminals must belong to the declassed upper class), and individual cases were not explained as being part of a larger plot against the Romanian communist state.

30 B ottoni: Transilvania roșie, op. cit., pp. 236-248.

31 The Soviet matrix has been extensively examined by Terry Ma r t in : The Affirmative Action Empire. Nations and nationalism in the Soviet Union 1923-1939. Itacha, London 2001; David Branden berger: National Bolshevism. Stalinist mass culture and the formation of modern Russian national identity 1931-1956. Cambridge Mass. 2002; on the Romanian case, see the outstanding biography of Ana Pauker by Robert Levy: Gloria și decăderea Anei Pauker [Glory and decline of A.P.]. Iași 2002; on the nexus between the ideological transformation of the Romanian communist system and the ethnic issue, see Vladimir T is m ă n e a nu : Stalinism for all Seasons: A political history of Romanian Communism. Berkeley 2003.

32 ACNSAS, fond Documentar, dosar 97, f. 8-15. 
On the contrary, the general meetings of high officers of the Securitate, called on several occasions between 1957 and 1958 were instrumented by Drăghici and his colleagues - among whom Nicolae Ceaușescu, at that time the energetic vice-secretary of the CC of the RCP - as a tribune to unmask and condemn the alleged infiltration of "fascist" and "revisionist" elements into the Hungarian minority. ${ }^{33}$ This new approach to the Hungarian issue was confirmed by the recently published "memories" of high-ranking Securitate officer Evghenie Tănase, written during the short-lived liberalization of 1967-68 with a self-defending purpose. Tănase described the increasing conflicts arisen over security risks assessment after 1956 between the centre and the (Hungariandominated) regional Securitate office of the Hungarian Autonomous Region. According to Tănase, colonel Kovács from Târgu Mureș used to stress in his reports that Romanian nationalism shall be considered as the main security threat, while after the Hungarian revolution the central apparatus had come to the conclusion that resurgent Hungarian nationalism had been grossly underappreciated so far, and Hungarian "fascists" are threatening the socialist state. ${ }^{34}$

The late 1950s and the early 1960s brought deep ethnic and cultural changes in the composition of the Securitate. As part of a general effort to get rid of mostly unskilled and ethnically "unreliable" cadres whose only merit was illegal activity before 1944, hundreds of first generation Securitate officers were pensioned or downgraded with administrative measures. Hungarian-born Securitate officers did not disappear from the scene, but their new generation tended now to belong to a new generation of professionals educated at the school of Romanian communist patriotism, like colonel Elemér Erdélyi, who became chief of Securitate of the newly established Szekler county of Harghiţa in 1968, and held this position until his replacement with an ethnic Romanian officer in $1980 .{ }^{35}$ Another ethnic Hungarian, lieutenant colonel Alexandru Csomós, was appointed in the 1970s assistant chief of Mureș county Securitate. ${ }^{36}$ Throughout the 1960s, Securitate became the first administrative body to "internalise" and practice the new national-communist ideology. According to archival sources, in his capacity as minister of Interior, Drăghici played an active role

${ }^{33}$ A detailed analysis of the 1957-1958 Securitate meetings in B o t t o $\mathrm{n}$ i : Transilvania roșie, op. cit., pp. 228-248.

34 Evghenie Tăn a se: Pseudomemoriile unui general de Securitate [Pseudo-memories of a Securitate-general]. București 2008, pp. 206-210.

35 Securitatea. Eds. D obre et al., op. cit., vol. 2, pp. 124-126.

36 Ibidem, pp. 189-191: 9 aprilie 1974 - referat de cadre al locotenent-colonelului Csomos Alexandru [9th of April 1974. Lecture by local responsable colonel C.A.]. 
in the stimulation of socialist patriotism. In his speech delivered to a large audience of high-ranking Securitate officers on 17 November 1964, the minister described security measures undertaken over the last two years in order to stop "nationalist propaganda" spilling over to Romania not only through the Western Hungarian emigration, but also from a neighbouring socialist ally, Kádár's Hungary. ${ }^{37}$ Preventive work and operative actions against the alleged centres of Hungarian revisionism (churches, schools, cultural networks) was intensified, and special attention was paid to the recruitment of ethnic Hungarian informers.

The switch towards an openly discriminative approach was motivated by external factors, such as the bilateral crisis in the relationship with the Soviet Union which followed the so-called "declaration of independence" issued by the RCP in April 1964 on the necessity to establish equal relationships between the communist parties of the socialist camp. In the meanwhile, Romania was reconsidering its military and security ties with the other members of the Warsaw Pact. After 1948, two long-standing enemies such as the Hungarian and the Romanian secret service had been forced by the international situation to start a (mostly informal) mutual cooperation under Soviet guidance. Throughout the 1950s and the early 1960s, the two security forces carried out several joint operations targeting former war criminals, nationalist intellectuals, or ordinary people from Hungary visiting relatives and friends in Romania. Bilateral diplomatic relationships deteriorated after the "declaration of independence", and so did the intelligence cooperation between the two ministries of Interior, which thus came to a long-lasting stop. ${ }^{38}$

After 1956 and 1964, the third and most decisive crisis to worsen the perception of the Hungarian minority by the Romanian state security came along in 1968, with the Prague Spring and the subsequent

37 Securitatea. Structuri - cadre. Obiective și metode. Eds. Florica Dobre et al., cit., vol. 1, pp. 615-651: Expunerea ministrului Afacerilor Interne, Alexandru Drăghici, referitoare la munca organelor de securitate in perioada octombrie 1963 - octombrie 1964, cu prilejul ședinței organizate la minister cu toate cadrele de conducere din aparatul central si regional MAI. Stenograma ședinței din 17 noiembrie 1964 [Explanation of the Minister of the Interior, A.D., relating to the task of Securitate from Oct. 1963 to Oct. 1964, on the occasion of the conference of the minister and all head cadres of the central and regional offices by the Ministry of the Interior. Stenogram of the meeting on 17th of November 1964].

38 On the Romanian-Hungarian intelligence cooperation see Stefano Bottoni: "Baráti együttműködés": a magyar-román állambiztonsági kapcsolatok ["Friendly co-operation": the relations of the Hungarian and Romanian intelligence agencies] (1945-1982). In: Történelmi Szemle 2 (2011), pp. 235-257. 
invasion of Czechoslovakia by the USSR and his allies. As Romanian and international scholars claim, after the 1968 Czechoslovak crisis, the Romanian authorities made further steps toward a new security doctrine focusing on national independence and territorial protection, setting up a special "anti-KGB" military unit (UM 110). ${ }^{39}$ The main targets of this unit were the USSR and the neighboring Hungary, whose leadership was suspected to fuel popular nationalism over the sensible issue of Transylvania. During the 1970s, formally recorded but highly ineffective security cooperation agreed between the two Ministries of Interior in 1972 could not cancel the emerging conflicts.

As the most update scholarship has pointed out, in the late 1960s the intellectual debates on the condition of Hungarian communities abroad had re-emerged in the Hungarian public sphere after almost twenty years of self-imposed silence, and played an outstanding role in the formation of the first opposition platforms to the Kádár regime. ${ }^{40}$ The interest many Hungarians showed in their co-ethnics living in the neighbouring countries became a source of increasing annoyance to the Romanian authorities, who considered every word spent on this topic as an intolerable intervention in a sovereign state's internal affairs. Since Hungary was a socialist country and a member of the Warsaw Pact, enjoying strong support from Moscow in its "national manoeuvres"

39 See Marius Oprea: Moștenitorii Securității [The heritage of the Securitate]. București 2004; Lavinia B e te a : 21 august 1968 - Apoteoza lui Ceaușescu [21 ${ }^{\text {st }}$ of August 1968 - The apotheosis of C.]. Iași 2009; for a more detailed account based on Romanian and East German sources Stejărel Olaru, Georg Herbstritt: Stasi și Securitatea. București 2005, especially pp. 109-118. According to Larry L. Watts, the post-1968 infiltration of the Soviet Bloc' security services into Romania would have been part of a larger plan aimed at destabilyzing the country. Larry L. W a t t s: Ferește-mă, Doamne, de prieteni! Războiul clandestin al blocului sovietic cu România [Save me, Lord, from friends. The secret war between Soviet Bloc and Romania]. București 2011.

${ }^{40}$ Katalin Miklós sy: Manoeuvres of National Interest. Internationalism and Nationalism in the Emerging Kádárist Criticism of Romania 1968-1972. Helsinki 2003; Martin Mevius: The Politics of History. Romanian-Hungarian historical disputes and the genesis of the "History of Transylvania". In: Entanglements and Comparisons: Hungary and Romania beyond national narratives. Eds. Anders Blom qvist, Constantin Ior d a chi, Balázs Terencsenyi . Ort??? Jahr??? (Stanford University Press, forthcoming). See also the general overview by Nándor Bárdi: Tény és való. A budapesti kormányzatok és a határon túli magyarság kapcsolattörténete [Real Facts. The history of the relationship between the governments in Budapest and the Hungarians abroad]. Pozsony, Kalligram 2004; on the Hungarian-Romanian relations György Földes: Magyarország, Románia és a nemzeti kérdés [Hungary, Romania and the nationality-problems] 1956-1989. Budapest 2007; a more theoretical approach in János Gyurgyák: Ezzé lett magyar hazátok? A magyar nemzeteszme és nacionalizmus története [What has become your country? The history of the Hungarian national idea and of the Hungarian nationalism]. Budapest 2007, pp. 501-534. 
against the Romanian national-communism, the emergence of an open conflict between two allies over the status of the Hungarian minority in Transylvania was out of question. In the 1970s and the 1980s, the Romanian security forces came to regard Hungary and the whole Hungarian community in Transylvania as a main security threat. Ignoring the rules of engagement of the Warsaw Pact countries, which forbade hostile intelligence activity on another member state's territory, the Romanian security services started to infiltrate the political, cultural and economic structures of Hungary. Although cautious reaction of the Budapest authorities to the Romanian offensive posture aimed to reassure Moscow about the good will and the accountability of the Kádár regime, no gesture of appeasement could prevent the further worsening of the bilateral relations in the first half of the 1980s. Then, the Hungarian minority in Transylvania suffered demographic losses due to assimilation and growing emigration, becoming the hostage of an unprecedented conflict among the two socialist countries.

\section{Collaboration as a sacrifice to the community: the case of Imre Mikó}

After sketching a general picture of the complex relationship between the Romanian state security and the Hungarian minority, I would conclude this study by touching upon the still very sensitive issue of the collaboration of a great number of ethnic Hungarians with Securitate. I will try to answer why they accepted to help a regime which did not favor them, and sometimes openly discriminated minorities, through the case of one of the most outstanding Transylvanian Hungarian intellectuals of the XXth century, Imre Mikó. ${ }^{41} \mathrm{He}$ was born in Kolozsvár/Cluj in 1911 from a distinguished Transylvanian family, whose members since 1848 had held almost uninterruptedly the position of Curator-general within the Transylvanian Unitarian Church. He started writing for several periodicals in the early 1930s, when he was one of the very few ethnic Hungarian students to attend the faculty of Law of the newly established Romanian-language university of Cluj, where he graduated. Between 1934 and 1936, he completed his studies in international law in Budapest and Paris, and then in 1937, at only 26, started a brilliant political career as chief of the Bucharest office

41 The only comprehensive, though incomplete biography of Mikó is Sándor B alá z s : Imre Mikó: Élet- és pályakép. Kéziratok, dokumentumok [The life and the career of Imre Mikó. Manuscripts and documents] (1933-1968). Kolozsvár 2003; see also Ernő Gáll's earlier portrait in: Imre Mikó: Változatok egy témra. Tanulmányok [Variations on a theme. Studies]. Bukarest 1981, pp. 9-23. 
of the Hungarian National Party of Romania. After 1938, when King Charles II introduced a personal dictatorship through the dissolution of all existing parties, Mikó remained in the capital as general secretary and chief of the legal office of the Hungarian minority's new umbrella organization, the Hungarian People's Community. In October 1940, after the Second Vienna Award gave back Northern Transylvania to Hungary, he left Bucharest, where he had been working since 1939 as the secretary of the Hungarian Popular Community, the Hungarian branch of the National Renaissance Front. By then the sober lawyer, who could speak an excellent Romanian along with English, German and French, had already become the most influent Hungarian politician in Transylvania. In 1941, Prime Minister Pál Teleki asked Mikó to become a member of the Hungarian parliament and to serve his community as the chief of the Budapest office of the Transylvanian Party. He fulfilled this duty until March 1944, when he resigned in sign of protest against the German military invasion of Hungary and returned to his native town. ${ }^{42}$

A decisive turning point in his life came after the Romanian/Soviet joint liberation of Kolozsvár/Cluj, on 13 October 1944, when based on the lists preliminarily drafted by the Soviet security services; he was arrested along with hundreds of prominent members of the Hungarian community and deported to a forced labor camp in the USSR. During the 4-years captivity, he learned Russian and became a political responsible for his camp. After his return to Cluj, in 1948, the newly learnt language proved essential for his survival: despite being a wellknown bourgeois politician, he was one of the few persons in Cluj to have good command of Russian, and so could become a teacher of Russian at his former Unitarian College. Ten years after, the Ministry of Interior ordered to dismiss all "politically unreliable" cadres from the education system. The punishment affected Mikó as well, whose reactionary past became the object of long investigations, during which he was forced to work for several years as a storekeeper of the regional editorial trust, being promoted later to manager of the university bookshop.

42 Mikó's involvement into the Hungarian political life is broadly documented in Nándor Bár r i's introduction "Egy girondista Erdélyben" [A girondist in Transsylvania] to Imre Mi kó: Az erdélyi falu és a nemzetiségi kérdés [The Transylvanian village and the nationality problem]. Csíkszereda 1998, pp. 5-36. On Mikó's political and intellectual role as an authoritative member of the Hungarian parliament between 1941 and 1944, see Gábor Eg ry: Az erdélyiség "színeváltozása". Kísérlet az Erdélyi Párt ideológiájának és identitáspolitikájának elemzésére [The "color change" of the Transylvanians. An attempt to analyze the ideology and identity politics of Erdélyi Párt/Transylvanian Party] 1940-1944. Budapest 2008. 
His political and social rehabilitation came in parallel with the evolution of the Romanian communist regime. In the second half of the 1960s, during the first, and relatively liberal, years in power of Nicolae Ceaușescu, Mikó regained his former status of Curator-general of the Unitarian Church, a position he filled between 1964 and 1969, and again after 1973. In this capacity, in August 1968 he organized the international celebration of the 400th anniversary of the Unitarian movement, celebrated with great pomp in Cluj as a sign of openness of the Romanian communist state towards a minority cult. After February 1970 he became one of the editors and most influential staff members of the newly established Kriterion publishing house specialized on publishing literature of minority communities, a position he covered until his death.

From 1948 to the day of his death, in March 1977, Mikó's professional and private life was accurately monitored by the Securitate, which mobilized several dozens of officers and secret informers to unveil the smallest nuances of the ordinary life of a "declassed" element under the communist regime. The Securitate archives in Bucharest (ACNSAS) hold an impressive ten-volume collection documenting the relationship between Mikó and the state security. Six of them contain more than 1300 pages of operative investigation carried out on Mikó (Fond Informativ), while the other four (734 pages) testify Mikó's secret cooperation with Securitate. He was recruited three times as an informer after 1948, when the secret police registered his comeback from the USSR and started spying on him. ${ }^{43}$ In February 1952, under physical and psychological constraint, he signed a cooperation agreement, but gave only little information about the pre-1944 activity of former colleagues and friends belonging to the liberal-conservative political side. In 1955, he suffered a short arrest, possibly motivated by his refusal to continue collaboration. After his release, he signed another agreement. Following the 1956 Hungarian revolution Mikó did not accept to speak about who had been supportive of the uprising among his colleagues and students, and wrote the first party secretary of Cluj region, asking for rehabilitation and denouncing his precarious condition as a police informer. Securitate reacted nervously to this rather unusual step, and after eliminating him from the collaborators' network (January 1957), they put him under general surveillance as a former leader of a "fascist party". In September 1958 Mikó also lost his job as a Russian language teacher, and the state security pressure increased on him, but he had become so prudent and suspicious, that

${ }^{43}$ Mikó's personal file in the Romanian secret police archives: ACNSAS, fond Informativ, dosar 235727 (6 vol.), and fond Rețea, dosar 182274 (4 vol.). 
all the attempts of the Securitate to provoke political debates among Mikó and his acquaintances spying on him proved to be unsuccessful.

The most interesting phase of his collaboration was definitely the third and last one (1972-77). When he regained all ecclesiastical honors and a widely respected job as assistant editor of the main Hungarianlanguage publishing house, Mikó again had to come to terms with the Securitate. This time, the stake was not his personal freedom like in the 1950s, but the broadly-shared idea of intellectuals of "paying their duty to the nation" by serving their community even at the price of personal sacrifice. On the one hand, Securitate allowed Mikó to travel several times to the West (1972, one-month trip to West-Germany and Austria; 1973, one-month trip to the US; 1976, one-month trip to West-Germany, Austria and Switzerland). The possibility for a respected member of the Hungarian "high society" to travel in Western countries, certainly not suspected of communist sympathy for his political past and cultural background, would dismiss widespread allegations among the Hungarian émigrés of mistreatment of the Hungarian minority in Transylvania. The Romanian secret police helped Mikó to get in contact with the Western Hungarian emigration, using him, codenamed since 1973 as informer "Micu" or "Marcu", as a channel of influence and disinformation. Information he gave through detailed written reports on the attitude of the Western emigration towards Transylvania and the minority problems was rated of highest relevance, and after his last mission in 1976, he personally discussed the outcome with the chief of the Cluj county Securitate office, General Constantin Ioana, an utmost rare privilege for an informer. Throughout the files, one can follow both the general evolution of the political system from open brutality to sophisticated manipulation techniques, and a former opponent's personal evolution from political and moral rejection of the communist regime to a critical conformation to it. The frightened and blackmailed petty informer of the 1950s by the mid-1970s had become a qualified source, whose diplomatic and analytic capacity was appreciated very much by the secret police.

What may have motivated the collaboration of Mikó with a system he ideologically never adhered to? In the 1950s, his only aim was to survive Stalinism and to avoid another fall to poverty for his large family as it had happened during his long absence between 1944 and 1948. The case is rather different when we come to the 1970s. Then Imre Mikó had an excellent reason for accepting to collaborate with the Romanian communist security services. As a skilled lawyer and politician, he was well aware of the kind of tasks and compromises such a cooperation implied, and also of the moral borderline he could 
not cross. The first and most important goal of his travels to the West was to strike up (or re-establish) relationships with the Hungarian diaspora and to show that the Transylvanian Hungarian community still exists, produces valuable culture and - at the end of the day - it is worth being supported morally, politically and economically. He knew or felt on the ground how suspicious the Western emigration was of anyone coming from the "iron curtain"; as one of the few trustworthy persons representing abroad the Transylvanian Hungarian community under Ceaușescu, Mikó accepted the rules of play set by the Securitate in order to fulfill a higher ethical expectation: staying at the service of his community.

Imre Mikó was not the only prominent member of the Hungarian minority to face after the Second World War the moral dilemma to resist or rather seek to integrate into the Romanian communist state. Many think that to cooperate with the central and local authorities was inevitable in order to physically preserve the community and avoid even harder repression, cultural assimilation or expulsion from Romania, even if the successfully uncompromising stance towards the national-communist regime of the Roman Catholic Bishop Áron Márton's shows that other options were possible, as well. Then, a closer study of the state security's perspective over the minority question gains importance to understand which paradigms and which rational choices marked the Romanian minority policy throughout the Communist era.

\section{Zusammenfassung}

Müsste deutsch sein!!! Integration, Collaboration, Resistance. The Hungarian Minority in Transylvania and the Romanian State Security Police

This paper proposes to look into the strained relationship between the Communist State Security and the most sizeable ethnic minority in Romania, namely the Hungarian community of Transylvania, comprising roughly 1.5 million people

Professional historians deating with ethnic relations in Communist Romania still keep looking into the pernicious effects of self-victimization and tratmatizing collective memory suffered by minority groups during the 1980s. Making use of previously inaccessible sources 
from the files of the former Secret Police archives, it is now possible to challenge the widely shared view that central and local Romantan authorities had been the only agents responsible for the maltreatment of minorities, exonerating former collaborators as victims of an infernal system.

In this paper a new methodology is set forward, allowing to reconstitute historical research on interetbulc relations in Transylvania by analyzing not only the actual policies conducted by the Romanian authorities, but also bebind-the-curtain manoeuvres affecting organizational and ideological changes carried out by Securitate. The fundamental shift in altitude of the Romanian Secret Police from strict internationalisn and class repression to open support of 'soft' ethnic cleansing ean be considered as one of the most interesting features among the more general substantial changes which the Romanian Communist regime underwent from the late 1950s onwards.

\section{Rezumat}

Integrare, colaborare, rezistență. Minoritatea maghiară din Transilvania și Securitatea română

In această conferință este analizată relația dintre Securitatea în statul comunist și minoritatea etnică cea mai numeroasă din România (în număr de 1,5 milioane) - cea a comunității maghiare în Transilvania.

Istorici de profesie, ocupându-se de relații etnice în România comunistă, continuă să releveze autovictimizarea, trauma memoriei colective, așa cum au fost ele construite în anii optzeci de grupuri minoritare. Prin cercetarea unor documente din arhivele poliției secrete, inaccesibile în trecut, acum este posibilă contestarea acestui punct de vedere, conform căruia numai autoritățile românești locale și centrale ar fi fost responsabile pentru tratamentul opresiv al minorităților, prin care foști colaboratori ar fi fost victime ale unui mecanism infernal.

Prin această conferință dorim să contribuim la o reînnoire metodologică a cercetărilor istoriei relațiilor interetnice în Transilvania, analizând nu numai politicile concrete ale autorităților românești, ci și schimbările organizatorice și ideologice efectuate de Securitate în secret. Remarcabilă în cadrul schimbărilor generale în anii cincizeci târzii a fost trecerea Securității de la internaționalism și conceptul luptei de clasă la sprijinirea unei politici de blândă epurare etnică. 